\title{
Finding the Gap: Student Stress and Student Engagement of First-Year Undergraduate Student from Overseas
}

\author{
Anissa Lestari Kadiyono ${ }^{1}$ and Annisa Nanda Liyani ${ }^{2}$ \\ Fakultas Psikologi - Universitas Padjadjaran, Indonesia ${ }^{1,2}$ \\ anissa.lestari@unpad.ac.id ${ }^{1}$
}

\begin{abstract}
A high school student who has decided to continue their study to the higher level will face a change of role and demands. State University as a higher education form government has accepted students from the various region. A first-year undergraduate student has to face lots of changes of their resources in the environment to meet the demands. This situation can make undergraduate student feel stress. Stress that happened to an undergraduate student could give effect to engagement and activeness of student and affect student's achievement. The aim of this research is to find out the correlation between student stress and student engagement of first-year undergraduate student from overseas. The subject of this research is 199 first-year undergraduate from faculty cluster of State University at West Java - Indonesia, which is Medical Cluster, Agro complex, Sosiohumaniora, and Science and Technology. The research method that is used is correlational with cluster sampling. The data was obtained with Student Stress modified questionnaire from [1] with 24 items and Student Engagement modified questionnaire from [2] with 14 items. The data was processed by using a correlational test to see if there a correlation between students stress and student engagement. The result of this research represents that there is a low negative correlation between student stress and student engagement of first-year undergraduate student from another region. This research has shown that the higher level of student stress will cause the lower level of student engagement of the first-year undergraduate from another region. It means that student stress effect the student engagement. These research findings can be applied at the university to make students more adaptable and have productive behavior in studying at higher education.
\end{abstract}

Keywords: Student Stress, Student Engagement, First-Year Undergraduate Students, Overseas Students.

\section{Introduction}

College has been a choice for student who had graduated high school. The desire to continue education to a higher level encourages high school graduates to pursue their dream to be accepted in favorite universities in Indonesia. In 2017, as many as 11 of 15 favorite state university in Indonesia is located on the island of Java, Indonesia (www.e-sbmptn.com). These favorite university has most applicants on national selection. This shows that there is a 
high tendency for high school students who have graduated to continue their education to Java Island which is outside their area.

This encourages students from outside the region who study in certain areas to continue their studies in state university in Java, Indonesia. This is known as overseas students. Overseas students are students who continue their education outside their home areas by going to other areas to seek knowledge. According to [3], there are six main elements of overseas students which is one who leaving their homes, according to their own volition, for a certain period of time, having a purpose for livelihood, studying or seeking experience, usually with the intention of returning home, in the sense of habits or behavior perpetrated by many, who are entrenched.

One of the state universities on the island of Java provides data that in the academic year 2016-2017, below is the distribution of data of student origin. This shows that students who come from outside West Java Province there are as many as 30\% of the total first-year undergraduate students of Padjadjaran University. This means that one-third of new students come from outside the region and must try to adjust to the new environment to be faced. There will be lots of differences and changes that they will face. In academic factor, they will face a different learning system. They will also face different culture and languages and have to have a responsibility for their daily needs, without any help from parents.

When entering a new environment, there will be many differences and changes when compared to the previous environment. As people migrating, individuals will try to find out the lifestyle, language, values, or norms contained in the new environment. These things can be different from their home region. This difference will not only be felt because of the movement from the area of origin to new areas, but also because of the displacement of high school students to under graduate students. Students must adapt to their living away from home for the first time, keep academic achievements high, and adapt to new social environments [1].

In addition to the academic factor, first-year students will experience changes in the social environment. As many as $30 \%$ of students coming from outside West Java Province will enter new areas with heterogeneous people and come from various regions. The origin of these different areas will affect their ways of interacting with others, mindsets, and behaviors that are often done. Therefore, the first-year students, must be able to adapt themselves to these differences in order to interact well in their new environment.

Table 1. Data Distribution of Student Origin

\begin{tabular}{|l|r|l|r|}
\hline \multicolumn{1}{|c|}{ Province } & \multicolumn{1}{c|}{ Size } & \multicolumn{1}{c|}{ Province } & Size \\
\hline Aceh & 20 & Lampung & 52 \\
\hline Bali & 7 & Maluku & 31 \\
\hline Banten & 207 & NTT & 3 \\
\hline Bengkulu & 13 & Papua & 10 \\
\hline DI Yogyakarta & 11 & Riau & 60 \\
\hline DKI Jakarta & 671 & Sulawesi Barat & 1 \\
\hline Gorontalo & 6 & Sulawesi Utara & 1 \\
\hline Jambi & 21 & Sulawesi Tenggara & 1 \\
\hline Jawa Barat & 4276 & Sulawesi Selatan & 15 \\
\hline Jawa Tengah & 108 & Sumatera Barat & 263 \\
\hline
\end{tabular}




\begin{tabular}{|l|r|l|r|} 
Jawa Timur & 57 & Sumatera Selatan & 22 \\
\hline Kalimantan Barat & 13 & Sumatera Utara & 185 \\
\hline Kalimantan Selatan & 2 & Bangka Belitung & 7 \\
\hline Kalimantan Tengah & 2 & Kepulauan Riau & 35 \\
\hline Kalimantan Timur & 10 & Abroad & 2 \\
\hline & & & Total \\
\hline
\end{tabular}

Resource: Rektorate Educational Section - Unpad 2017

Personal life on the overseas first-year students will be changed. If they had been accustomed to living with their parents, now they would have to live alone. The consequences that will be faced from living separately from parents is to be able to take care of personal needs and be able to choose activities that will not interfere with his or her personal life, without any help from parents. In addition, they can not get immediate social support either from their parents, relatives, or from their closest friends.

These changes can cause stress for first-year undergraduate students. Psychological stress is a particular relationship between the person and the environment that is appraised by the person as taxing or exceeding his or her resources and endangering his or her well-being [4]. Stress is something that happens because of the interaction between humans and their environment. Psychological stress is the relationship between humans and the environment that will be judged by human beings as something more or less than the resources possessed and endanger the human well-being. There are two main concepts in stress theory, there are appraisal and coping. Appraisal is how individuals judge a state as stressful or not. [4] proposed three types of stress: stress caused by things lost or damaged, caused by the loss or destruction of a thing that might happen and threaten the individual (threat), and because it challenges the individual (challenge). When things in the environment are rated as challenging, the individual will continue to work to solve them. But when things in the environment are rated as threatening or disturbing, individuals will experience negative stress.

Based on this definition, it can be seen that there are 2 things that can be a cause of stress that is felt by someone, that is:

a. Extreme environmental conditions. Environmental conditions that can be a cause of stress is an environment that can cause damage or distress in a person. In this study, it can be seen that there is a change in the lives of migrant students. Based on preliminary data obtained, the four things that undergo these changes become the factors that cause stress in overseas students, they are:

1. Academic Factor, ie changes in the academic system

2. Environment Factor, ie changes to the campus environment as well as the current residence

3. Interpersonal Factor, ie changes in interpersonal relationships

4. Intrapersonal Factor, ie changes that occur in the self when facing a new environment

b. Cognitive appraisal. An environment that can cause stress in a person can not necessarily cause stress in others. This is due to individual differences in assessing whether a situation can threaten its well-being or not.

If the oversear first-year student feels that the surrounding environment is giving a negative stress, then the immigrant student will have a certain impact from it. Based on research conducted by [5], stress tends to increase in first-degree students and can have an effect on the physical and emotional health of students [6]. Other studies have also revealed 
that higher stress conditions in college students may lower their student engagement [7] in [6]. This shows a negative correlation the state of stress perceived by student engagement students.

According to Job Demand-Resource Model [8], when the resources owned by students are not in accordance with the demands they have, the student can experience stress. Resources in the form of Personal Resource that will provide capital to individuals to run their potential and activities optimally [9]. Human resources are the main factor driving other resources, so this becomes the main factor that needs to be managed [9]). This perceived stress can then affect the engagement of students, especially when the resources it possesses can interfere with the vigor, dedication, and absorption of students in meeting the demands possessed [10]. This can be explained as follows:

a. Vigor, is a desire and high energy level given to the work done. This is supported also by mental resilience when facing difficulties in the completion of tasks

b. Dedication, is a strong individual involvement in work and has enthusiasm, pride, feelings of inspiration and challenge to work

c. Absorption, is the last aspect of engagement. A person who has high levels in this aspect will give full concentration to his work so that he feels lost time and difficult to get away from the job.

Work Engagement is a positive, fulfilling, affective-motivational state of world-related well-being that can be seen as the antipode of job burnout [8], [10]. The effects of these changes can influence the engagement of students on their academic performance. Based on this definition, we know that engagement is a motivational concept [11]. When a student feels engage with the activities and life of the lecture, they will give optimal effort to the activity. But when the student not feel engage, they will not be motivated to provide optimal effort in his lectures. Students are not employed by the university or college where they study. But the tasks of students who have structure of activities, such as attending classes and collecting assignments, may be referred to as a 'job' [12], [13]. Therefore, students can feel attachment or burnout in their 'job' or assignment as a student. Research conducted by [14], shows that a individual's stress can cause burnout and can also show signs of dysfunctional behavior when the person can not cope with the stressor appropriately.

When the overseas first-year students experience stress caused by the things that face, can affect the attachment in the university activities because it can not function in accordance with the role they have. This situation is also supported by other studies that reveal that higher stress conditions in students may lower their student engagement [7] in [6].

Student engagement is an important condition for students to feel during the study. Student engagement has been shown to influence graduates, classroom motivation, and attainment in lectures [15]-[17]. As students become more motivated to learn, they will be more successful in their education [17]. Based on the results of the study, students who do not have high student engagement will tend to be unmotivated to learn and obtain optimal results. Students will feel stress in their life aspects, such as academic, environmental, and interpersonal. The stress felt by this student can affect student engagement. This research will answers how stress and student engagement experienced by overseas students at state university in Java Island become first year students.

\section{Literature Review}

The aim of this section is to clarify the methodology of this research. This section will explain the research sample, research design and instruments that were used for data collection. 


\subsection{Sample}

Population of participant in this study is first-year undergraduate student from other region form Universitas Padjadjaran as state university at Sumedang-Java, Indonesia. This study used cluster sampling that showed minimum sample is 178 students. Participants come from four cluster of faculty in Universitas Padjadjaran, which is Health Cluster, Agrocomplex Cluster, Sosiohumaniora Cluster, and Science and Technology Cluster. The sample of the study included 199 students. Grouping of faculties based on these clusters is the basis of cluster sampling, from which each cluster will be taken each randomly from one faculty. The selection of one faculty as representative of the cluster is done so that the samples taken can represent the students of Universitas Padjadjaran. Here is a table of faculty selection from each cluster faculty of Universitas Padjadjaran:

Table 2. Primary Sampling Unit

\begin{tabular}{|l|l|}
\hline \multicolumn{1}{|c|}{ Kluster } & \multicolumn{1}{c|}{ Fakultas Sampel } \\
\hline Health Cluster & Fakultas Psikologi \\
\hline Agrocomplex Cluster & Fakultas Teknologi Industri dan Pertanian \\
\hline Sosiohumaniora Cluster & Fakultas Hukum \\
\hline $\begin{array}{l}\text { Science and Technology } \\
\text { Cluster }\end{array}$ & Fakultas Geologi \\
\hline
\end{tabular}

Participants have such criteria:

- first-year students at Universitas Padjadjaran

- Oversear Student (from outside Bandung Regency, West Bandung Regency, Bandung City, Cimahi City, and Sumedang Regency)

Do not live with parents or close family.

\subsection{Research Design}

Research design of this study is non-experimental research with cross-sectional design. Non-experimental research is a descriptive study to obtain a description about phenomena that happened [18]. Research method of this study is correlational. The aim of this study is to find out the correlation between student stress and student engagement of Universitas Padjadjaran's first-year undergraduate student from other region.

\subsection{Instrument}

Student Stress questionnaire was developed from Student Stress Scale [1]. It consists of four factors of stressor for first-year undergraduate from other region with 24 items. The factors that will be measured are academic factor, environment factor, interpersonal factor, and intrapersonal factor. Student stress has reliability measured using Cronbach alpha and the score is 8.73 which is reliable questionnaire. The second questionnaire that will be used was modified from Uthrecht Work Engagement Scale-Student (UWES-S) [2]. It consists of vigor (5 items), dedication (5 items), and absorption (4 items). It has Cronbach alpha as 8.86 which is realiable.

\section{Result and Discussion}

Respondents from the study amounted to 199 people with 80 men and 119 women. The results of the study show that there is a negative correlation between student stress and student engagement. Spearman correlation coefficient correlation test showed that it score is - 0336, 
which means when the students are getting stressed, the engagement will be lower. Psychological stress is a particular relationship between the person and the environment that is appraised by the person as taxing or exceeding his or her resources and endangering his or her well-being [4]). First-year students who come from different region and currently studying will certainly feel some changes. The changes felt by the new students who migrated will be interpreted as threatening or even challenging. When a person uses his environment as threatening, then the person can feel stress about what is happening around him. There are four factors that can cause stress on students, such as academic, environment, interpersonal and intrapersonal factor. The level of stress experienced by overseas students can be seen in the picture as follows:

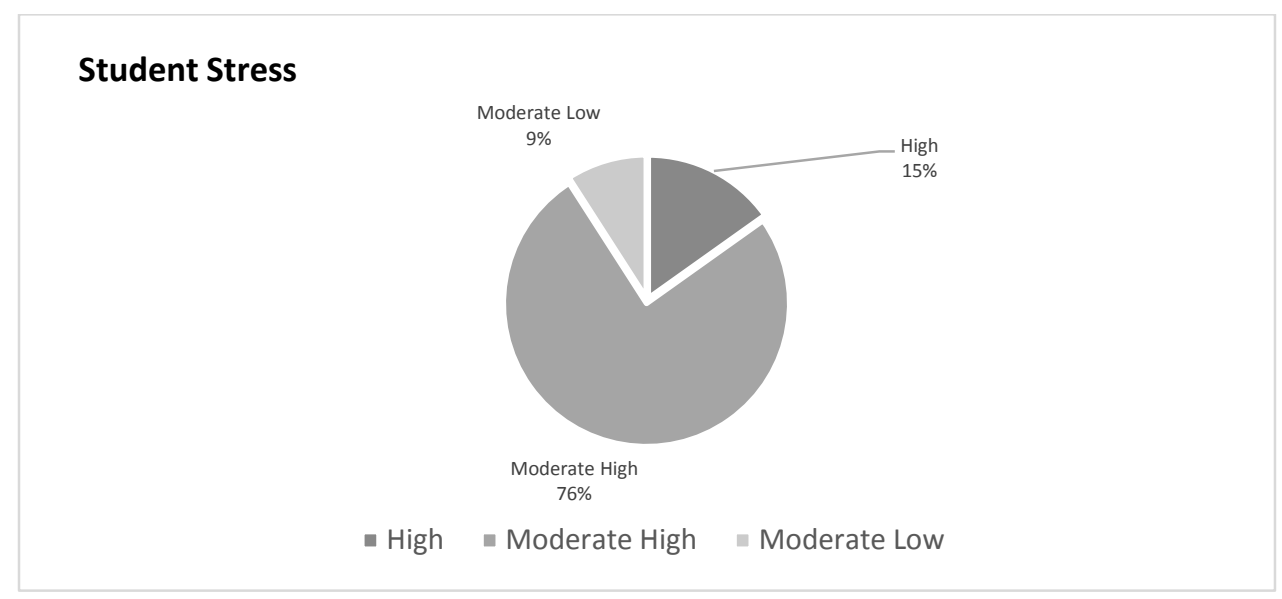

Fig. 1. Percentage of Students Stress

From the picture above, obtained data that migrant students who are in the stress category category were 152 people $(76 \%)$. This indicates that the migrant students feel that their resources tend to be less to face the new environment they face while they are students at public universities in Java. Based on the dimensions of student stress as follows:

Table 3. Student Stress Dimension

\begin{tabular}{|l|c|c|}
\hline \multicolumn{1}{|c|}{ Dimensions } & P-value & Explanation \\
\cline { 1 - 1 } Academic Factor & & \\
\cline { 1 - 1 } Environment Factor & 0.007 & H0 is rejected \\
\cline { 1 - 1 } Interpersonal Factor & & \\
\cline { 1 - 1 } Intrapersonal Factor & &
\end{tabular}

The above test results indicate that there are differences in the forming dimension of stress on students, and based on data that academic factors play the biggest role in the occurrence of stress in new students. This can be seen in the correlation coefficient as follows:

Table 4. Student Stress Correlation

\begin{tabular}{|l|l|l|}
\hline \multirow{2}{*}{ Dimension } & \multicolumn{2}{|c|}{ Student Engagement } \\
\cline { 2 - 3 } & Correlation & P-Value \\
\hline
\end{tabular}




\begin{tabular}{|l|c|c|}
\hline & Coefficient & \\
\hline Academic Factors & $-0,476$ & 0,000 \\
\hline Environmental Factors & $-0,088$ & 0,215 \\
\hline Interpersonal Factors & $-0,226$ & 0,001 \\
\hline Intrapersonal Factors & $-0,232$ & 0,001 \\
\hline
\end{tabular}

Academic factors are things that include the suitability of the study, the adjustment of learning methods, how to understand the different lecture materials in the high school, which makes the lecture life becomes increasingly felt difficult and stressful. The condition felt by the immigrant students is then seen by their attachment in performing the duties as a student. Student engagement is a positive state associated with well-being and can be seen as an antipode of a job burnout. A person who engage will have high energy and engage in his activities [10]. Based on the results of analysis, as follows:

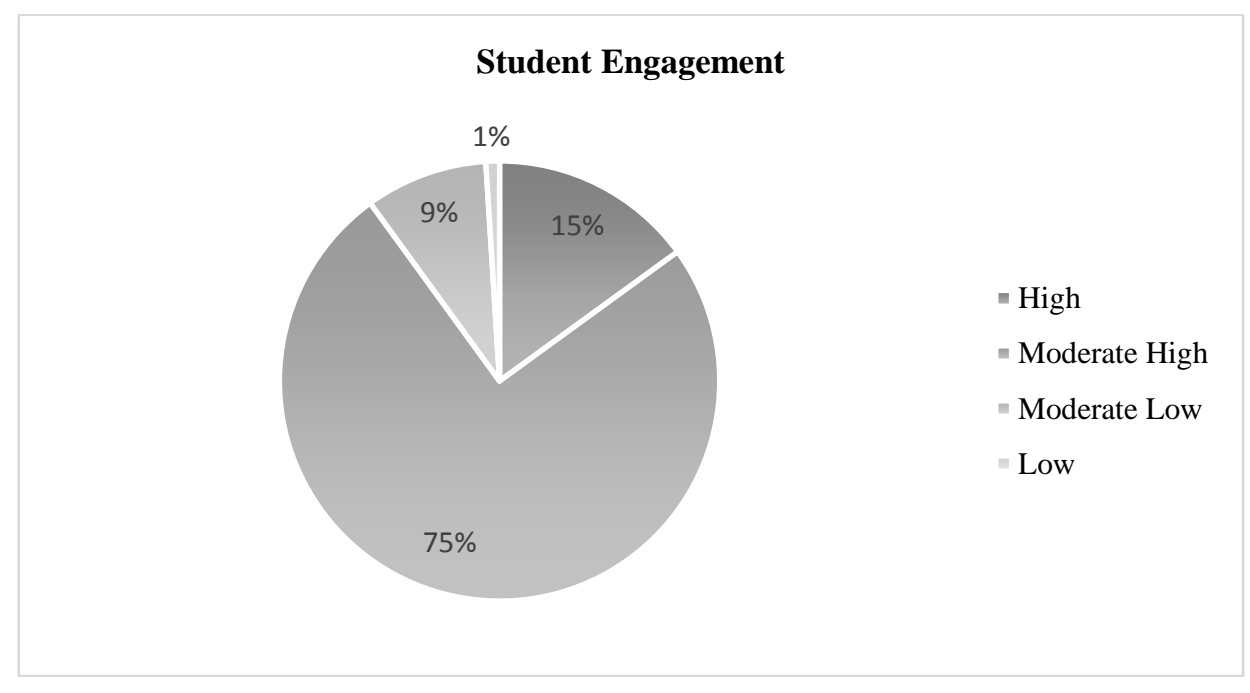

Fig. 2. Percentage of Student Engagement

Based on the figure above, the student engagement student level is generally at a high tendency level (75\%). This indicates that the immigrant student has enough positive thoughts, is fulfilled, and has enough feeling involved in his duties as a student. Seen from its forming dimension, this condition can be seen as follows: 


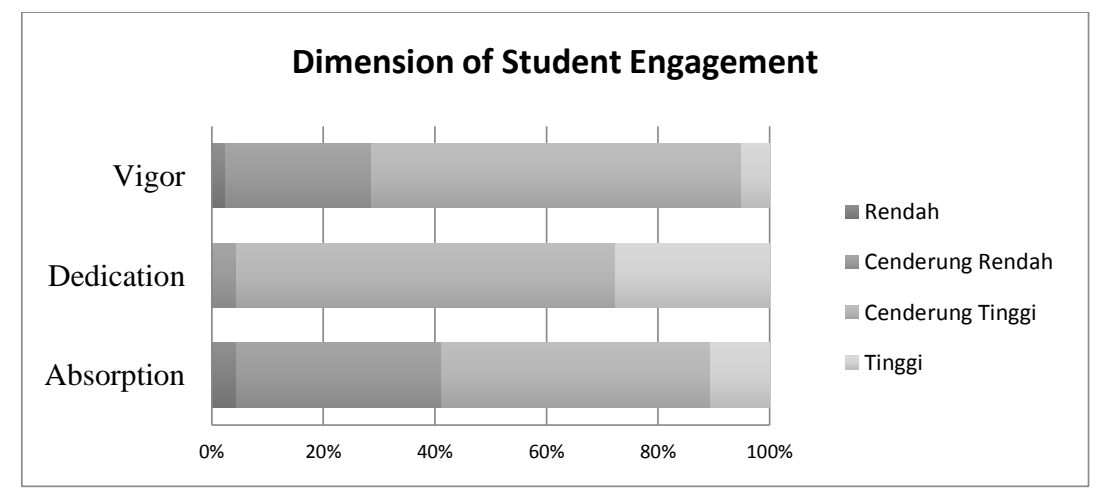

Fig. 3. Dimension of Student Engagement

Based on the table above, it can be seen that the major of respondents who follow this research have a high level of student engagement in the three dimensions of student engagement. Based on the analysis of the data, it can be seen that the immigrant students feel excited when studying the material in accordance with the faculty. Despite the obstacles, the first-year students have the enthusiasm and pride to study at the state university. They also feel inspired and challenged by the field of lectures that are being occupied.

In testing of the proposed hypothesis, student stress and student engagement significantly related at first-year students of the University of Padjadjaran. Based on the Spearman correlation test, correlation coefficient can be seen which shows the degree of relationship between variables and p-value which shows the significance of relationship between variables as follows:

Table 5. Correlation between Student Stress and Student Engagement

\begin{tabular}{|l|c|c|}
\hline \multicolumn{1}{|c|}{ Variable } & $\boldsymbol{P}$-value & $\begin{array}{c}\text { Coefficient } \\
\text { Correlation }\end{array}$ \\
\cline { 1 - 2 } Student Stress & 0.000 & -0.336 \\
\cline { 1 - 2 } Student Engagement & & \\
\hline
\end{tabular}

Based on the spearman correlation test, p-value $<0.05$, which means $\mathrm{H} 0$ is rejected. This shows that student stress and student engagement have a significant relationship. Student stress and student engagement have a negative relationship. This means that the higher the student stress experienced by overseas students, the lower the student engagement will be felt by them. According to Job Demands-Resources Model, stress is generated by an imbalance between the demands faced with the resources owned by workers [19]. Students' demands for education require students to learn things that are appropriate to their field of knowledge. Things that are included in education is to study, do a good job, and consider things that happen rationally. The subsequent demands of research and development require students to implement the knowledge gained through research. The research is not only to develop student it self, but also to university to make overseas student more productive. Students are also required to develop soft-skill that is owned scientifically and academically in order to be able to think critically in facing the existing environment.

To meet these demands, students have resources both within themselves and from the environment. The resources of the student are self-efficacy, self-esteem (organizational 
based), and optimism. These resources will work together with the resources that come from the environment to meet the demands they have. As first-year students, they will face several changes from both academic, environmental, interpersonal, and intrapersonal factors. Changes experienced in this academic field of learning system changes into a SKS system. In this SKS system, lecturers do not have full role in the delivery of materials as teachers, so that students must actively seek teaching materials. Changes in the environment can be seen from the current environment that is different from the original environment. Then changes in interpersonal relationships can be seen from the diverse student areas that can influence the mindset, culture, and language. Changes in the field of intrapersonal can be seen from the ability of students to take care of all their own needs because they have to migrate and stay separated from their parents. These changes are actually the resources they have to meet the demands.

As the first-year student faces changes in their environment, the student will try to deal with those changes with their self-esteem, self-efficacy and optimism resources [20]. The resources available to these students will determine whether they are capable of coping with changes in their environment. Therefore, when student's judge that changes to things that act as resources from within themselves and the environment can not meet the demands and ultimately disrupt the well-being, the student can feel stressed.

[4] states that stress occurs because of an assessment of what is going on around it with the resources it has. This shows that when the immigrant college students assesses the changes that occur at the beginning of the lecture as something that can disturb them, it can cause stress. Based on the results of the study, the great challenge facing students is the transition period where they have to live separately with parents for the first time, maintain and improve academic achievement, and put themselves in a new environment [1], [21]. Based on study, immigrant college students have moderate stress level. This is in line with the results of research showing that this transition period is a process of change and adjustment followed by challenges and stress for emerging adults to meet the personal demands of the academic and social environment. Changes faced to meet the demands of both academic, environmental, interpersonal and intrapersonal relationships make students stress.

According to the Burnout journal, the stress experienced by a person can cause burnout and can also show signs of dysfunctional behavior when the person can not cope with the stressor appropriately [14]. When stress can not be overcome, a person experiencing stress can experience dysfunction that can affect its performance, especially in their study progress. Other studies also explain that higher stress conditions in college students can lower their student engagement [6], [22]. When student engagement is owned by students low, students can not give optimal results during their education. This is in accordance with the results of research showing that active engagement can improve learning and personal development in the classroom [23]. Student engagement also positively correlates with academic results of values and diligence in learning [24]. Student engagement is an important thing for students to have. So if the assessment of the environment conducted by migrant students can cause stress, this may affect student engagement owned by immigrant students.

The relationship between student stress and student engagement is low. The relatively low relationship between student stress and student engagement variables makes the student can not have high student engagement level because of the level of stress that is classified as being. Relationships found only in the low category because there are still personal resources owned by immigrant students. These personal resources can assist students in using resources from the environment to meet their demands. However, the relationship can not be explained because the limitations of research that only examine the relationship between student stress 
caused by changes in academic, environmental, interpersonal and intrapersonal relationships with student engagement owned by immigrant students.

Dimensions of academic factors are the dimensions that have the greatest degree of relationship. The results show that academic demands and pressures as well as limited time for themselves and the environment can cause student stress and negatively affect students [25]. Based on the analysis of data on the highest item, it can be known that the first-year students often feel uncomfortable following the lectures. Based on the supporting data, 5.5\% of students feel that the system assigned tasks are different from the high school assignments, as many as $14 \%$ feel that the tasks are difficult with short deadlines, $3.5 \%$ of students feel that the lecture schedule is too dense with a lot of material. Then $11.5 \%$ of students feel that the material received is very difficult to understand, it is related to the statement of $9 \%$ of students who feel that the way lecturers teach is very different than when high school and make the student becomes difficult to understand the material given. Stressor that can affect the level of stress felt by students and most often faced by students during the teaching and learning process so that students often feel not in the mood to follow lectures. This can interfere with student engagement, especially in the dimensions of dedication, so that students are not so enthusiastic to attend the lecture activities.

The next dimension after academic factors is intrapersonal factors. As many as $9.54 \%$ of students feel less able to manage time well so many tasks are left behind, as many as $8 \%$ of students find it difficult to manage finances well so they do not pay attention to health by eating healthy food, related also with $3 \%$ too careful about his health. Due to having to leave the area of origin to college and separated from parents, as many as $5 \%$ of students find it difficult to manage their own needs because they are accustomed to assisted by parents. This factor explains the lack of ability of students in managing their own needs since life separated with parents. Students claimed not yet accustomed to organize activities, time, and own finances. The result of data analysis according to the highest score, it is found that since college, the student becomes less concerned about his health. This happens because the lack of students' ability to manage finances so that they can not pay attention to health well. The results showed that the engagement of students experiencing financial stress will be affected, such as not participating in lectures because they do not have enough money and the financial interest that can affect the academic performance [26]. This lack of attention to health can affect student engagement students especially in the vigor dimension. Impaired health can make students unable to provide optimal energy when attending lectures. This can make the students become unattached fully to the lecture activities. The results of this study are similar to studies conducted by Oh, [21].

There is no relationship between interpersonal factor and student engagement. This shows that the stress experienced by students does not affect student engagement owned. Based on the data analysis of the highest score of items, it can be seen that students find it difficult to adjust to the mindset of friends who come from the region. This did not affect student engagement because the area was disturbed only on the relationships during group work. However, based on the analysis of the lowest score data, it can be seen that students do not find it difficult to get closer to friends who come from different areas. In accordance with the data indicating that the student's origin does not affect the difference in the student stress level experienced, the student can have a good relationship with friends who come from different regions and do not disturb the level of student engagement they have. 


\section{Conclusion}

There is a negative relationship between student stress and student engagement. This indicates that the higher the student stress students have, the lower the student engagement the overseas students have. The pressures that come from the new environment faced by immigrant students can reduce their attachment to lecturing activities at their faculty.

The thing that most influence student stress student level is academic in the form of difference from teaching method of lecturer, system of assigned task, and others. Therefore, each faculty can develop a program that can help first-year students to recognize the learning system at faculty.

First-year students entering new environment feel stressed when faced with new demands and different resources compared to resources in the previous environment. In addition to the academic factor, changes in the intrapersonal aspect also make new students feel difficult to interact with their environment. Faculty can arrange programs to help students recognize the values that exist in each faculty and facilities and infrastructure faculty that can support lectures activities.

Academic factor becomes the dimension that most have relationship with student engagement student. This shows that most academic affects students' engagement. The relationship between student stress and student engagement is low. This can be caused by the measurement of personal resources of students in fulfilling their demands.

\section{References}

[1] S. E. Ross, B. C. Niebling, and T. M. Heckert, "Sources of Stress Among," Coll. Students. Coll. Student J., vol. 33, no. 2, p. 312.

[2] W. B. Schaufeli, M. Salanova, V. Gonzalez-Roma, and A. Bakker, "THE MEASUREMENT OF ENGAGEMENT AND BURNOUT: A TWO SAMPLE CONFIRMATORY FACTOR ANALYTIC," APPROACH. J. Happiness Stud., vol. , pp. 71-92.

[3] R. W. LINGGA, GAMBARAN VIRTUE MAHASISWA PERANTAU. Medan: Universitas Sumatera Utara.

[4] R. S. Lazarus and S. Folkman, Stress, Appraisal, and Coping. New York: Springer Publishing Company, Inc.

[5] E. J. Krumrei-Mancuso, F. B. Newton, E. Kim, and D. Wilcox, "Psychosocial factors predicting first-year college student success," J. Coll. Stud. Dev., vol. 54, no. 3, pp. 247-266.

[6] M. N. Krypel and D. Henderson-King, "Stress, coping styles, and optimism: are they related to meaning of education in students'," lives? . Soc Psychol Educ, vol. , pp. 409-424.

[7] C. Gan and Wijun, "Wang,(2017)'The influence of perceived value on purchase intention in social commerce context," Internet Res. Vo, vol. 27, no. 4, pp. 772-785.

[8] A. B. Bakker and E. Demerouti, "The Job Demands-Resources model: state of the art," J. Manag. Psychol., vol. , pp. 309-328.

[9] A. L. Kadiyono, "Pengaruh Human Capital Terhadap Positive Organizational Behavior Melalui Motivasi Kerja Dan Komitmen Organisasional Sebagai Mediator (Studi Empirik Pada Pegawai Divisi Marketing Di Bumn Bidang Jasa Wilayah Jawa Barat) The Influences Of Human Capital To Positive Organizational Behavior Through Work Motivation And Organizational Commitment As Mediating Variables (The Empirical Study At," in Marketing Division Employees In The State Owned Enterprises Of Services Industry In West Java), Doctoral dissertation: Universitas 
Padjadjaran.

[10] A. B. Bakker and M. P, "Work Engagement : A Handbook of Essential," Theory Res.

[11] M. Batubara and A. L. Kadiyono, "No Title," in WORK ENGAGEMENT AS A PREDICTOR OF LECTURER'S PERFORMANCE. In Proceeding 10th ADRI 2017 International Multidisciplinary Conference and Call for Paper, Batam, p. 109.

[12] W. E. Leland, M. S. Taqqu, and D. V. Wilson, "On the Self-Similar Nature of Ethernet Traffic (Extended Version)," IEEE/ACM Trans. Netw., vol. 2, no. 1, pp. 1$15,1994$.

[13] G. Friedman, Student Stress, Burnout and Engagement. Faculty of Humanities. Johannesburg: University of the Witwatersrand.

[14] A. Tereszko, K. Drozdowicz, M. F. Szymura, B. Taurogiński, A. Tuleja, and W. Korzeniowski, "Burnout, neurotic symptoms and coping strategies in medical students," Psychiatry Psychother., vol. 4, pp. 17-22.

[15] A. M. Lee, H. de Zúñiga, R. Coleman, and T. J. Johnson, The dialogic potential of social media: Assessing the ethical reasoning of companies' public relations on Facebook and Twitter. Ethical practice of social media in public relations. New York, NY: Routledge.

[16] S. C. Flynn, Feminist Theories And Social Work: Approaches and Apllications. New York: The Haworth Press.

[17] C. Schwarz, "The Impact of Student Expectations in Using Instructional Tools on Student Engagement: A Look through the Expectation Disconfirmation," Theory Lens . J. Inf. Syst. Educ., vol. 26, pp. 47-58.

[18] L. B. Christensen, Experimental Methodology. USA: Pearson Education, Inc.

[19] M. P. Leiter and A. B. Bakker, Work engagement: A handbook of essential theory and research. Psychology press.

[20] A. L. Kadiyono and S. Sumantri, "Identifikasi Hambatan Organisasi Dalam Memberdayakan Sumber Daya Manusia Serta Hubungannya Dengan Kepuasan Kerja Karyawan. Abstrak.”.

[21] E. J. Oh, C. A. Blondin, J. L. Cochran, and R. L. Williams, "Perceived Stressors among College Students in an American and a," Korean Univ. . Korean Soc. Sci. J., vol. 38, pp. 81-113.

[22] E. Gender and R. and Brand, "No Title," in Differences, Sex Roles 66:440-452, .

[23] P. A. Savyanavar, B. Mehta, V. Marathe, P. Padvi, and M. Shewale, "Multi-Document Summarization Using TF-IDF Algorithm," Int. J. Eng. Comput. Sci., vol. 5, no. 4, pp. 16253-16256, 2016.

[24] S. F. Maher, "The Effects of Engagement Activities on Pre-Physical Therapy Students Across One Semester of Class," Student Engagem. Exp. J., vol. , pp. 2-25.

[25] M. Z. Bataineh, "ACADEMIC STRESS AMONG UNDERGRADUATE STUDENTS: THE CASE OF EDUCATION FACULTY AT KING SAUD,” Univ. Int. Interdiscip. J. Educ., vol. 2, pp. 82-89.

[26] K. Fosnacht and Y. Dong, Financial Stress and Its Impact on First-Year Students College Experiences. St. Louis, MO: Association for the Study of Higher Education. 